\title{
A Brief Review about Ayurveda
}

\section{Definition of Ayurveda}

The word "AYURVEDA" is a combination of two words - 1. Ayur (means life) 2. Veda (means science)

So we have to know both of the words to know "AYURVEDA".

\section{Ayur}

We want to live a healthy life. Mostly and generally, we were healthy by birth. But due to climatic condition, food, life style and by some important factors by our mother and father we engaged with some physical, mental and anatomical problems. Definitely we want to cure ourselves, so we try to find solutions for a healthy life.

Ayurveda described each and every thing about healthy life (mental, physical, and anatomical) since thousands of the years.

The main classical books of ayurveda are Charak samhita, Susrut samhita, Ashtang Hridayam. Commonly we can say them "Vrihatrayi". Ayurveda is also called as " ${ }^{\text {th }}$ veda". It means, ayurveda is an important part of "atharv veda".

\section{Veda}

Veda means science. A complete source which helps to know in a proper way. According to Ayurvedic philosophy an individual bundle of 'spirit', desirious of expressing itself, uses subjective consciousness or Satwa to manifest sense organs and a mind. Spirit and mind then project themselves into a physical body, created from the five (Pancha) great (maha) eternal elements (bhutas)-together called the Panchamahabhutas -which arise from Tamas. The sense organs then using Rajas to project from the body into the external world to experience their objects. The body becoming the mind's vehicle, its physical instrument for sense gratification.

The Bhutas combine into "tridoshas" or bioenergetic forces that govern and determine our health or physical condition. While the three gunas (Rajas or activity, Tamas or inertia and Satwa, which balances the first two) or psychic forces determine our mental and spiritual health. Ayurvedais thus a holistic system of health care that teaches us to balance these energies in order to achieve optimum health and well being.

\section{History}

The main source of knowledge in this field therefore remains the Vedas, the divine books of knowledge they propounded, and more specifically the fourth of the series, namely Atharvaveda that dates back to around $1000 \mathrm{BC}$. Ayurveda is the oldest surviving complete medical system in the world. Derived from its ancient Sanskrit roots - 'ayus' (life) and 'ved' (knowledge)- and offering a rich, comprehensive outlook to a healthy life, its origins go back nearly 5000 years. To when it was expounded and practiced by the same spiritual rishis, who laid the foundations of the Vedic civilisation in India, by organising the fundamentals of life into proper systems.

\author{
Review Article \\ Volume 5 Issue 6 - 2017 \\ Arpit Kumar Ranawat* \\ Aradhya Ayurvedic Hospital \& Panchkarma research Centre, \\ India \\ *Corresponding author: Arpit Kumar Ranawat, Aradhya \\ Ayurvedic Hospital \& Panchkarma research Centre, 42 , \\ tirupati nagar, behind railway station road, Near baafna deep \\ school, Mandsaur 458001(M.P.) India, Tel: +91-9584737163; \\ Email: doctorarpitranawat@gmail.com
}

Received: May 24, 2016 | Published: March 15, 2017

Of the few other treatises on Ayurveda that have survived from around the same time, the most famous are Charaka Samhita and the Sushruta Samhita which concentrate on internal medicine and surgery respectively. The Astanga Hridayam is a more concise compilation of earlier texts that was created about a thousand years ago. These between them forming a greater part of the knowledge base on Ayurveda as it is practiced today.

The art of Ayurveda had spread around in the 6th century BC to Tibet, China, Mongolia, Korea and Sri Lanka, carried over by the Buddhist monks travelling to those lands. Although not much of it survives in original form, its effects can be seen in the various new age concepts that have originated from there.

No philosophy has had greater influence on Ayurveda than Sankhaya's philosophy of creation and manifestation. Which professes that behind all creation there is a state of pure existence or awareness, which is beyond time and space, has no beginning or end, and no qualities. Within pure existence, there arises a desire to experience itself, which results in disequilibrium and causes the manifestation of the primordial physical energy. And the two unite to make the "dance of creation" come alive.

Imponderable, indescribable and extremely subtle, this primordial energy- which and all that flows from its existing only in pure existence-is the creative force of all action, a source of form that has qualities. Matter and energy are so closely related that when energy takes form, we tend to think of it in terms of matter only. And much modified, it ultimately leads to the manifestation of our familiar mental and physical worlds.

It also gives rise to cosmic consciousness, which is the universal order that prevades all life. Individual intelligence, as distinct from the everyday intellectual mind, is derived from and is part of this consciousness. It is the inner wisdom, the part of individuality that remains unswayed by the demands of daily life, or by Ahamkara, the sense of 'I-ness'.

A Sanskrit word with no exact translation, Ahamkara, is a concept not quite understood by everyone as it is often 
misleadingly equated to 'ego'. Embracing much more than just that, it is in essence that part of 'me' which knows which parts of the universal creation are 'me'? Since 'I' am not separate from the universal consciousness, but 'I' has an identity that differentiates and defines the boundaries of 'me'. All creations therefore have Ahamkara, not just human beings.

There arises from Ahamkara a two-fold creation. The first is Satwa, the subjective world, which is able to perceive and manipulate matter. It comprises the subtle body (the mind), the capacity of the five sense organs to hear, feel, see, taste and smell, and for the five organs of action to speak, grasp, move, procreate and excrete. The mind and the subtle organs providing the bridge between the body, the Ahamkara and the inner wisdom, which three together is considered the essential nature of humans.

The second is Tamas, the objective world of the five elements of sound, touch, vision, taste and smell- the five subtle elements that give rise to the dense elements of ether or space, air, fire, water and the earth- from which all matter of the physical world is derived. And it is Rajas, the force or the energy of movement, which brings together parts of these two worlds.

\begin{tabular}{|c|c|c|c|c|}
\hline $\begin{array}{c}\text { Dense } \\
\text { Element }\end{array}$ & $\begin{array}{c}\text { Subtle } \\
\text { Element }\end{array}$ & $\begin{array}{c}\text { Sense } \\
\text { Organ }\end{array}$ & $\begin{array}{c}\text { Motor } \\
\text { Organ }\end{array}$ & Function \\
\hline Space & Sound & Ears & $\begin{array}{c}\text { Vocal } \\
\text { chords }\end{array}$ & Speaking \\
\hline Air & Touch & Skin & Hands & Grasping \\
\hline Fire & Sight & Eyes & Feet & Moving \\
\hline Water & Taste & Tongue & Genitals & Procreating \\
\hline Earth & Smell & Nose & Anus & Excreting \\
\hline
\end{tabular}

It is worth noting that even at the stage of the dense elements the philosophy of creation-which according to Sankaya is now and in the present, without any past and any future- is still dealing with aspects of existence beyond our simple physical realms. The point of contention being that we are the first and foremost spirit experiencing existence. To use Ayurveda in daily life, one has neither to accept nor even understand this philosophy. But it does provide a deeper insight into how Ayurveda works towards betterment of your health.

Ayurveda therefore is not simply a health care system but a form of lifestyle adopted to maintain perfect balance and harmony within the human existence, from the most abstract transcendental values to the most concrete physiological expressions. Based on the premise that life represents an intelligent co-ordination of the Atma(Soul), Mana (Mind), Indriya (Senses) and Sharira (Body).

That revolves around the five dense elements that go into the making of the constitution of each individual, called Prakriti. Which in turn is determined by the vital balance of the three physical energies - Vata, Pitta, Kapha and the three mental energies - Satwa, Rajas, Tamas.
Ayurveda thus offers a unique philosophy that balances the physical, mental, emotional and spiritual components necessary for holistic health.

\section{Eight Branches of Ayurvedic}

Ayurveda, being a vast science is divided into eight branches, which are collectively called as Ashtang Ayurveda. Like any other modern medicinal therapies, Ayurveda believes in specialized treatment for different body parts. Thus, the medicinal art have been categorized under branches that deal with psychiatry, internal medicine, treatment of eyes, ears, nose, throat and head, toxicology and gerentorology separately. Ayurveda is the first ever medicine system to categorize pediatrics, aphrodisiacs and surgery as the branches of any medicinal science.

\section{List of the eight branches}

i. Kayachikitsa -Internal Medicine

ii. Shalya chikitsa -Surgery

iii. Bala chikitsa- Pediatrics

iv. Graha chikitsa- Bhoot Vidya - Psychiatry

v. Urdhvanga chikitsa-Treatment of eyes, ears, nose, throat and head

vi. Damstra chikitsa- Agad Tantra -Toxicology

vii. Jara chikitsa- Rasayana- Gerentorology

viii. Vrishya chikitsa- vajikarana- Aphrodisiacs

\section{Agada Tantra}

Ayurveda is oldest medical science known to mankind and mainly aims at healthy living and long life unlike other medical science which simply focus on the treatment of ailments and diseases. According to Ayurvedic science, there should be proper balance between the inner constituent elements of the body for a healthy existence.

\section{Kaumara Bhritya}

Ayurveda is a very elaborate and vast medicinal science. It deals with several kinds of complex ailments and surgeries. The science of Ayurveda is divided into eight different categories in order to clearly demarcate the treatment of one ailment from another. That is why the science of Ayurveda is often referred as Astang Ayurveda i.e. the life science with eight branches.

\section{Graha Chikitsa}

Ayurveda is an ancient medicinal science. It originated in the Indian subcontinent about 5000 years ago and is considered to be one of the most advance medical therapies existing in the world till now. In contemporary times, it has also gained popularity in the western world and is considered to be a form of complementary and alternative medicine (CAM).

\section{Rasayana Chikitsa}

Rasayana Chikitsa is the branch of Ayurvedic science, which deals with various aspects of preventive health care. This branch 
of Ashtang Ayurveda aims at achieving a long and healthy life. It includes longevity, improved memory, health, youthfulness, glow, complexion, generosity, strength of body and senses.

\section{Kayachikitsa}

Ayurveda is the holistic approach, which is mainly concerned with the treatment of the body. In the process, the person undergoes a change in the lifestyle, which includes change in food, clothing and sometimes even residence. Ayam and vyayam, yogasadhana and gati are some of the vital components that are included in an ayurvedic treatment.

\section{Shalakya Tantra}

One out of the eight branches of Ayurveda, Shalakya Tantra deals with the etiology, diagnosis, prognosis, prevention and treatment of diseases that are located above the neck region such as the head, ear, nose, eye and throat. It is responsible for all types of problems in and around the head.

\section{Shalya Chikitsa}

In the ancient India, surgery was principally pioneered by Ayurveda. Shalya Chikitsa is a significant branch of Ayurvedic science. The name of the sage-physician, Susruta, is synonymous with surgery. From his treatise Susruta Samhita, we have become aware of the thousand of years ago sophisticated methods of surgery that were practiced in India.

\section{Vrishya Chikitsa}

Vrishya Chtikitsa is a branch of Ayurveda that explains the art of producing healthy progeny for the creation of a better society. It deals with various diseases like infertility and conditions relating to weak shukra dhatu or the vital reproductive fluids of the body. Vrishya Chtikitsa is also known as Vajikarana, which means the medicine or therapy by which a man becomes capable of copulating with a woman.To know about ayurveda, we have to understand in following basics of ayurveda-
i. Tridosha
ii. Sapt dhatu
iii. Panch maha bhoot
iv. Swastha vritta
v. Rog vinishchaya
vi. Chikitsa

\section{A. Tridosha}

"TRI" means three and "DOSHA" is hypothetical factors of ayurveda which are most essential for the body. So the "tridosha" are
a. Vata
b. Pitta
c. Kapha

Ayurveda described all diseases and wellness on the basis of "TRIDOSHA".

I. Vata- this is most important dosha of the body.

\section{i. Importance of Vata}

\section{Pittam Pangu Kafam pangu, Pango mal dhatavah,}

Vayun yatra niyanti tatra gachchhanti meghvata.

II. Means -Pitta is immobile, Kapha is immobile, mala and sapta dhatus are immobile. As air direct clouds to move same like Vata is direct them to move in body. According to ayurveda vata leads more diseases compare to pitta and kapha.

\section{ii. Features of vata}

Vata governs movement in the body, the activities of the nervous system and the process of elimination. Vata influences the other doshas.

\section{iii. Qualities of Vata}

Cold, light, dry, irregular, rough, moving, quick, changeable

If Vata dosha predominates, movement and change are characteristic of your nature. You will tend to always be on the go, with an energetic and creative mind. As long as Vata is in balance, you will be lively and enthusiastic, with a lean body.

\section{iv. Physical characteristics}

Those with a predominance of Vata dosha are usually have a thin, light frame and excellent agility. Their energy comes in bursts, and they are likely to experience sudden bouts of fatigue. Vatas typically have dry skin and hair and cold hands and feet. They sleep lightly and their digestion can be sensitive. When the Vata dosha becomes imbalanced, it manifests in the body as weight loss, constipation, hypertension, arthritis, weakness, restlessness, and digestive challenges.

\section{v. Emotional characteristics}

Vatas love excitement and new experiences. They are quick to anger but also to forgive. When Vatas are in balance, they are energetic, creative, and flexible. They also take initiative and are lively conversationalists. When unbalanced, they are prone to worry and anxiousness and often suffer from insomnia. When they feel overwhelmed or stressed, their response is, "What did I do wrong?"

\section{vi. Balancing Vata}

If excessive stress in your life leads to your Vata force becoming imbalanced, your activity will start to feel out of control. Your mind may race, contributing to anxiety and insomnia. You may start skipping meals, resulting in unintended weight loss, and your digestion may become irregular. If you notice these early symptoms of a Vata imbalance, slow down, take time to meditate, don't skip meals, and get to bed earlier. A regular lifestyle routine helps ground Vata so you are not carried away into the ethers.

i. Vata is cold, light, irregular, dry, and always changing. To balance Vata, make choices that bring warmth, stability, 
and consistency to your life.Try to get to bed before 10pm, awaken by $6 \mathrm{am}$, and eat your meals at regular times.

ii. Avoid becoming chilled. Wear adequate clothing appropriate for the season and keep your head covered when the weather is cold.

iii. Perform a daily self-abhy massage using warmer, heavier oils like sesame and almond.

They experience periods of high energy, but they also tire easily. Light exercise that enhance balance and flexibility is best for a Vata body type. Take care not to push yourself too far and exceed the limits of your energy. Beneficial activities for Vatas include: yoga, Qi Gong, Tai Chi, walking and short hikes, light bicycling, light tennis, golf, dance, and aerobics.

Fresh ginger root is beneficial and can be used frequently.During the cool weather, sip ginger tea throughout the day.

Be certain that your bowels move regularly on a daily basis.

Favor soothing, calming music.

Touch and be touched regularly by the people you love.

Favor warm colors in your clothing and environment such as earth colors, pastels, browns, and warm yellows.

Favor aromas that are sweet, heavy, and warm. Examples include basil, bay, cinnamon, citrus, cloves, frankincense, lavender, pine, sage, and vanilla.

\section{vii. Vata-balancing nutritional guidelines}

According to ayurveda, it is important to eat foods that have a balancing effect upon the dominant dosha or that will pacify (stabilize) a dosha that has become excessive or aggravated. Since Vata is drying, cooling and light, favor foods that are oily, warming, or heavy. The best tastes to pacify Vata are sweet, salty and sour. Minimize foods that are pungent, bitter, or astringent.

\section{viii. Recommendations}

i. To balance the lightness of Vata, eat larger quantities, but don't overeat.

ii. All sweeteners pacify Vata and may be taken in moderation.

iii. Fats and oils are beneficial in the digestive system and help reduce Vata. Use up to 3 teaspoons daily of ghee or extra virgin olive oil.

iv. All low-fat dairy products are recommended. Milk is easier to digest when warm or heated.

v. Rice and wheat are the best grains for balancing Vata. Reduce the amount of barley, corn, millet, buckwheat, and rye.

vi. Favor sweet, heavy fruits such as: bananas, avocados, mangoes, apricots, plums, berries, coconut, figs, grapefruit, orange, lemon, melons, papaya, peaches, pineapples, rhubarb, kiwi, dates, nectarines and dried fruits.

vii. Eat fewer dry or light fruits such as apples, cranberries, pears, and pomegranates. To ease digestion, fruits are best eaten lightly cooked or sautéed or eaten alone.
Cooked vegetables are best. Raw vegetables should be minimized. Favor Asparagus, beets, and carrots. Other vegetables may be taken in moderation if cooked in ghee or extra virgin olive oil, including peas, broccoli, cauliflower, zucchini, and sweet potatoes.

Sprouts and cabbage tend to produce gas and should be minimized.

Dairy products pacify Vata. For optimal digestion, boil milk before drinking it and consume it while warm.

Spices that pacify Vata include cardamom, cumin, ginger, cinnamon, salt, cloves, mustard seed, basil, asafetida, cilantro, fennel, oregano, sage, tarragon, thyme, and black pepper.

All varieties of nuts are recommended.

Beans can aggravate Vata, so minimize your consumption of them, with the exception of tofu and mung bean dahl.

For non-vegetarians, use fresh, organic chicken, turkey, seafood, and eggs.

Note: Favoring heavy foods such as sweets, oils, and richer foods may contribute to weight gain. Focus on natural grains, and heavy, moist fruits and vegetables. Keep your sweets to a minimum and use low-fat milk products. Cook your food for easy digestion.

\section{b. Pitta}

This is second dosha of the body. Generally it refers to heat/ fir. All sensation of the body which represent heat or burning sensation of body are related to the Pitta dosha.

The Pitta dosha controls digestion, metabolism, and energy production. The primary function of Pitta is transformation.

\section{i. Qualities of Pitta}

Hot, light, intense, penetrating, pungent, sharp, acidic. Those with a predominance of the Pitta principle have a fiery nature that manifests in both body and mind.

\section{ii. Physical characteristics}

Pittas are usually of medium size and weight. They sometimes have bright red hair, but baldness or thinning hair is also common in a Pitta. They have excellent digestion, which sometimes leads them to believe they can eat anything. They have a warm body temperature They sleep soundly for short periods of time and have a strong sex drive. When in balance, Pittas have a lustrous complexion, perfect digestion, abundant energy, and a strong appetite. When out of balance, Pittas may suffer from skin rashes, burning sensations, peptic ulcers, excessive body heat, heartburn, and indigestion.

\section{iii. Emotional characteristics}

Pittas have a powerful intellect and a strong ability to concentrate. When they're in balance, they are good decision makers, teachers, and speakers. They are precise, sharp-witted, direct, and often outspoken. Out-of-balance Pittas can be shorttempered and argumentative.When Pittas are overstressed, their typical response is "What did you do wrong?" 


\section{iv. Balancing Pitta}

i. Pitta is hot, sharp, sour, pungent, and penetrating. To balance Pitta, we need to make choices that are cooling, sweet, and stabilizing.

ii. Balance rest and activity allowing some free time every day. Be careful not to create unnecessary time pressures for yourself.

iii. Be certain not to skip meals and do not wait until you are famished to eat. Favor foods that are sweet, bitter and astringent. Favor cooling foods such as cucumbers, sweet fruits and melons.

iv. Regularly spend time in nature. Take walks in the woods and along natural bodies of water. Keep plants and fresh flowers in your home and office. Walk in the moonlight.

Perform a daily oil massage using cooler oils such as coconut or olive.

Favor cooler colors in your clothing and environment such as blues, greens, and silver.

Laugh many times each day!

Favor aromas that are cooling and sweet. Sandalwood, rose, jasmine, mint, lavender, fennel, and chamomile are recommended.

\section{v. Pitta-balancing nutritional guidelines}

Since an excess of Pitta dosha overheats the mind and body, favor cool foods and liquids. Foods with sweet, bitter, and astringent tastes are best. Reduce foods that are pungent, salty, and sour.

\section{vi. Recommendations}

i. Dairy can be helpful in balancing the heat of Pitta, take milk, butter and ghee. Sour, fermented products such as yogurt, sour cream and cheese should be used sparingly as sour tastes aggravate Pitta. Ghee (clarified butter) is recommended.

ii. All sweeteners may be taken in moderation except molasses and honey.

iii. Olive, sunflower, and coconut oils are the best oils to pacify Pitta. Use less sesame, almond, and corn oil, which are more heating.

iv. Wheat, rice, barley, and oats are the best grains to reduce Pitta. Eat less corn, rye, millet, and brown rice.

v. The sweeter fruits such as grapes, melons, cherries, coconuts, avocados, mangoes, pomegranates, fully ripe pineapples, oranges, and plums are recommended. Reduce sour fruits such as grapefruits, apricots, and berries.

vi. The vegetables to favor are asparagus, cucumbers, potatoes, sweet potatoes, green leafy vegetables, pumpkins, broccoli, cauliflower, celery okra, lettuce, green beans, and zucchini. Reduce tomatoes, hot peppers, carrots, beets, eggplant, onions, garlic, radishes, and spinach. vii. Pitta types need to use seasonings that are soothing and cooling. These include coriander, cilantro, cardamom, saffron, and fennel. Hotter spices such as ginger, cumin, black pepper, fenugreek, clove, salt, and mustard seed should be used sparingly. Very hot seasonings such as chili peppers, and cayenne are best avoided. Chew on fennel seeds after meals to cool down acid in the stomach.

viii. For non-vegetarians, chicken, pheasant and turkey are preferable; beef, seafood, and eggs increase Pitta and should be minimized.

\section{c. Kapha}

It represents power, strength, heaviness, passion etc. its features little same to vata dosha. But vata has dryness which is opposite of kapha dosha.

Kapha governs the structure of the body. It is the principle that holds the cells together and forms the muscle, fat, bone, and sinew. The primary function of Kapha is protection.

\section{i. Qualities of Kapha}

Heavy, slow, steady, solid, cold, soft, oily.

\section{ii. Physical characteristics}

Kapha types have a strong build and excellent stamina. Large, soft eyes; smooth, radiant skin; and thick hair are also important Kapha characteristics. Those who are predominantly Kapha sleep soundly and have regular digestion. But when Kapha builds to excess, weight gain, fluid retention, and allergies manifest in the body. When they're out of balance, Kapha types may become overweight, sleep excessively, and suffer from asthma, diabetes, and depression.

\section{iii. Emotional characteristics}

Kaphas are naturally calm, thoughtful, and loving. They have an inherent ability to enjoy life and are comfortable with routine. When in balance, Kaphas are strong, loyal, patient, steady, and supportive. People with an excess of Kapha tend to hold on to things, jobs, and relationships long after they are no longer nourishing or necessary. Excess Kapha in the mind manifests as resistance to change and stubbornness. In the face of stress, the typical Kapha response is "I don't want to deal with it."

\section{iv. Balancing kapha}

i. Since Kapha is inherently cold, heavy, and dense, the key to balancing Kapha is stimulation. Kaphas tend to cling to the status quo and routine, so they need the stimulation of new sights, sounds, and experiences.

ii. Follow a regular daily routine, ideally awakening before 6am each morning. Avoid taking naps during the day.

iii. Stay warm and avoid dampness. Kaphas are particularly sensitive to cold, damp conditions and benefit from heat. Use dry heat if you are congested (a common Kapha complaint). Using a heating pad under your back or a sunlamp at your chest is often helpful. Avoid exposing your nose, throat, and lungs to cold winter air if you aren't feeling well. 
iv. Perform a daily garshan (dry massage) on your body to stimulate circulation.

To prevent congestion, the ayurvedic neti pot is a powerful tool for nasal cleansing.

Clear your space. To avoid clutter from accumulating in your home, office, car, and other physical spaces, regularly clean out and give away things that you know you'll never use.

Get regular exercise- preferably every day. This is the best way to avoid stagnation and the accumulation of toxins in the body. Focus on building endurance. Favor running, bicycling, swimming, aerobics, and competitive sports. Dance to energizing rhythmic music.

Use warm, stimulating aromas including cloves, camphor, cinnamon, eucalyptus, juniper, and marjoram.

Favor colors that are warm and bright, including yellow, orange, and red.

\section{vii. Kapha-balancing nutritional guidelines}

According to ayurveda, it is important to eat foods that have a balancing effect upon the dominant dosha or that will pacify (stabilize) a dosha that has become excessive or aggravated. Because Kapha is heavy, oily and cold, favor foods that are light, dry, or warm. Foods with pungent, bitter, and astringent tastes are most beneficial for pacifying Kapha. Reduce foods with sweet, sour, and salty tastes.

\section{viii. Recommendations}

i. Try a liquid fast one day per week, ingesting only fresh vegetables and fruit juices, and pureed vegetable soup.

ii. Reduce the intake of dairy, which tends to increase Kapha. You can use small amounts of ghee, low-fat milk, and low-fat yogurt.

iii. Honey is a sweetener that is said to best pacify Kapha. Other sweeteners should be avoided because they increase the Kapha dosha, contributing to problems such as blocked sinuses, allergies, colds, and lethargy. Take a tablespoon or two (but no more) of raw honey every day helps release excess Kapha; please do not cook with honey.

iv. Drinking hot ginger tea with meals helps stimulate slow digestion and sharpen dull taste buds. Drink 2 to 3 cups of ginger tea daily.

V. All beans are good for Kapha types except for soybeans and soybean-based foods such as tofu, which should be eaten in moderation.

vi. Favor lighter fruits such as apples, pears, pomegranates, cranberries, and apricots. Reduce heavier fruits like bananas, avocados, pineapples, oranges, peaches, coconuts, melons, dates, and figs.

vii. In general, all vegetables are recommended but reduce consumption of sweet and juicy vegetables such as sweet potatoes, tomatoes, and zucchini. viii. All spices except salt are pacifying to Kapha. Use pungent spices like pepper, cayenne, mustard seed, and ginger freely in your diet.

ix. Reduce intake of all nuts and seeds. Favor pumpkin seeds and sunflower seeds.

x. For non-vegetarians, fresh, organic white meat chicken, turkey, eggs, and seafood are acceptable. Limit consumption of red meat.

xi. A Kapha diet should be lively and full of energy to help spark the digestive and metabolic systems. Eat your largest meal at lunchtime and a smaller meal at dinnertime. Allow at least 3 hours to digest before bedtime.

xii. Fats and oils: Use small amounts of extra virgin olive oil, ghee, almond oil, corn oil, sunflower oil, mustard oil, or safflower oil.

xiii. Grains: Favor barley, corn, millet, buckwheat, rye. Reduce intake of oats, rice, and wheat.

\section{B. Saptdhatu (7 essential elements)}

Ayurveda described anatomy, physiology of the body in a another hypothetical way, which call as dhatus.

According to ayurveda, human body have seven dhatu, which regulate normal and abnormal anatomy and physiology of the body.

The Sapta (seven) Dhatus (tissues) elements form the pillars of the body that form the means of nourishment and growth while providing support to the body as well as the mind. As followings

$\begin{aligned} \text { i. } & \text { Rasa } \\ \text { ii. } & \text { Rakta } \\ \text { iii. } & \text { Mansa } \\ \text { iv. } & \text { Meda } \\ \text { v. } & \text { Asthi } \\ \text { vi. } & \text { Majja } \\ \text { vii. } & \text { Shukra }\end{aligned}$

i. Rasa: Derived from the digested food, it nourishes each and every tissue and cell of the body and is analogous to the plasma.

ii. Rakta: Regarded as the basic of life, it is analogous to the circulating blood cells. It not only nourishes the body tissues, but provides physical strength and colour to the body.

iii. Mansa: The muscle tissue, its main function is to provide physical strength and support for the meda dhatu.

iv. Meda: Consists of adipose tissue providing support to ashti dhatu. It also lubricates the body.

v. Asthi: Comprising of bone tissues, including cartilages, its main function is to give support to the majja dhatu and provide support to the masma dhatu. 
vi. Majja: Denoting the yellow and red bone marrow tissue, its main function is to fill up the ashti and to oleate the body.

vii. Shukra: The main aim of this reproductive tissue is to help reproduction and strengthen the body.

All dhatus formed in a particular order in our body. Firstly when we use to eat food then our dhatwagni starts to make dhatus start with rasa, then rakta, mansa, meda, asthi, majja and lastly shukra.

There is some concept of formation of all dhatus in the body.

a. Kedari kulya Nyaya

b. Khale kapot nyaya

c. Ek kal dhatu poshan nyaya

Since the dhatus support and derive energy from each other, affecting one can influence others. For instance, interference in the manufacture of the plasma affects the quality of the blood, which in turn affects the muscle. Each tissue type has its own agni, which determines metabolic changes in the tissues. And forms byproducts, which are either used in the body or excreted. Menstural periods for example are a by-product of rasa. The tissues are also governed by the three doshas, and any imbalance in them also causes imbalances in dhatus. Heavy periods therefore can also be caused by the effects of the excess of Kapha on plasma.

\section{The malas}

Malas are the various waste products of the dhatus produced during the normal metabolical process. The three primary malas being Purisa(faeces), Mutra (urine) and Sweda (sweat). Ayurveda clearly states that only a balanced condition of doshas, dhatus and malas is arogya (good health or disease free condition) and their imbalance is the cause of ill health or disease.

Purisa is the waste left back after nutrients of digested food have been absorbed in the small intestine. While water and salt absorbed in the large intestine, the residue now converted into solid faces, leaves the body. The consistency of the faeces depending both on gastrointestinal mobility and nature of diet.

The tridosha must be in balance to ensure normal evacuation. Pitta and kapha help digestion and vata governs the mobility throughout the process. Any discrepancy or imbalance between these can lead to various symptoms of abdominal heaviness or pain, flatulance, constipation or diarrohea. It may also give rise to diseases as rheumatoid arthritis, osteoarthritis, low-back pain, asthama, bronchitis as well as stomach ulcers and irritable bowels.

Mutra is derived during the course of biological processes within the human body. The first stage of urine formation begins in the large intestine where fluids are absorbed into the system. The entire urinary system (kidneys, uterus, bladder and urethra) takes part in the formation and elimination of urine, regulating the fluid balance in our body and also maintaining blood pressure. Any imbalance of increased or decreased urine may result in disorders as kidney stones urinary infections, cystitis, abdominal pain and bladder disorders.

Sweda is the third primary mala, and it occurs as a waste product during the synthesis of meda dhatu (fatty tissue). Eliminated through skin pores, it controls body temperature and helps to regulate the electrolytic balance. The channels responsible for bringing the sweat to skin surface are known as sweda vaha srotas. It is essential that normal formation and flow of sweat takes place as otherwise it may lead to skin infections, itching/ burning sensation over the body, loss of fluid balance and reduced body temperature.

Balanced Doshas (humours), healthy Agni, a good state of tissues and their metabolic end- products lead to a balanced state of the senses, mind and spirit, all of which lead to health.

\section{Tripods}

In Ayurveda, food (Ahar), sleep (nidra) and brahmacharya (controlled sex) are regarded as the three pillars or tripods of healthy living. It is important for our body to be adjusted to timely intake of good quality and proper food, regular sleeping habits and controlled indulgence in sex because as all this ensures long and healthy life. It is thus vital to have a regular systematic food and sleeping habit so that the body has a regularized automatic system of maintenance. It is even mandatory to maintain a balanced sex life and avoid extra indulgence worldly life. This practice of celibacy along with a proper daily regime not only promotes life and preserves health but also give enrichment to the soul and other cognitive organs and the mind. Given below is the description of the three pillars or tripods of healthy living- Three Tripods In Ayurveda.

a. Diet: We are what we eat. So, it is essential to know what to eat, when to eat, how much to eat and how to eat. Though there are concepts of generalized diets, which are applicable to one and all, Ayurveda says that it is the individual who knows best what suits his body and mind and he should thus, act accordingly. The popping of all the vitamin pills in the world is not going to make you healthy - for all you know your body might just reject them. One important principle in Ayurveda is that 'there is nothing in the world which is not a good food', it is only the combination of several factors that renders a substance unfit for consumption for a particular individual while the same substance might be absolutely palatable and digestible and in fact, good for the health of another individual.

The second important point to be noted that whatever the substance, however good it may be, if taken in excess, will become toxic and harmful to the body. Timely and moderate eating habits will serve you well.

b. Sleep: Give your body sufficient rest and find out what a different person you are! In pursuit of all the material benefits and comforts, you treat your body like a donkey; use it to the extent you can; and finally are an exhausted person when you have the comforts. When you give your overheated car time to cool off, can't you give your over used body time to recover from the stress and strain? Happiness and sorrow, growth and wasting, strength and weakness, virility and impotence, knowledge and ignorance, life and its cessation - all are dependent on sleep. 
c. Celibacy: Total abstinence from sexual activity may not be possible for ordinary mortals - but a restrained sexual life, keeping in mind the higher goal of eternal happiness, is certainly possible. Sexual promiscuity leads to various diseases. It is therefore very important to take care of your sexual health apart from other factors like diet and sleep.

\section{E. Panchmahabhoota (five elements)}

Ayurveda also accept panchmahabhoota concept.

The concept is "Each and everything of the universe is made up of panchmahabhoota."

It means that everything of the universe that visible or nonvisible but made up of panchmahabhoota (five elements).
a) These are
i. Aakash (Space)
ii. Jal (water)
iii. Agni (fire)
iv. Vayu (Air)
v. Prithvi (earth/solid)

\section{b) In human body}

i. Akash represent space in our organs, vessels etc

ii. Jal represent watery things in our body like blood, lymphatic fluid, CSF etc.

iii. Agni represent heat and energy, sometimes we can say digestive capacity also. iv. Vayu represent flow and movement and nervous system.

v. Prithvi represents solid part of the body. Every part of the body who has shape represent Prithvi.

According to Ayurveda everything in life is composed of the PanchamahabhutasAkash (Space), Vayu (Air), Jal (Water), Agni (Fire) and Prithvi (Earth). Omnipresent, they are mixed in an infinite variety of relative proportions such that each form of matter is distinctly unique. Although each element has a range of attributes, only some get evident in particular situations. Constantly changing and interacting with each other, they create a situation of dynamic flux that keeps the world going.

Within a simple, single living cell for example the earth element predominates by giving structure to the cell. The water element is present in the cytoplasm or the liquid within the cell membrane. The fire element regulates the metabolic processes regulating the cell. While the air element predominates the gases therein. The space occupied by the cell denoting the last of the elements.

In the case of a complex, multi-cellular organism as a human being for instance, akash corresponds to spaces within the body (mouth, nostrils, abdomen etc.); vayu denotes the movement (essentially muscular); agni controls the functioning of enzymes (intelligence, digestive system, metabolism); jal is in all body fluids (as plasma, saliva, digestive juices); and prithvi manifests itself in the solid structure of the body (bones, teeth, flesh, hair et al).

The Panchmahabhutas therefore serve as the foundation of all diagnosis \& treatment modalities in Ayurveda and has served as a most valuable theory for physicians to detect and treat illness of the body and mind successfully.

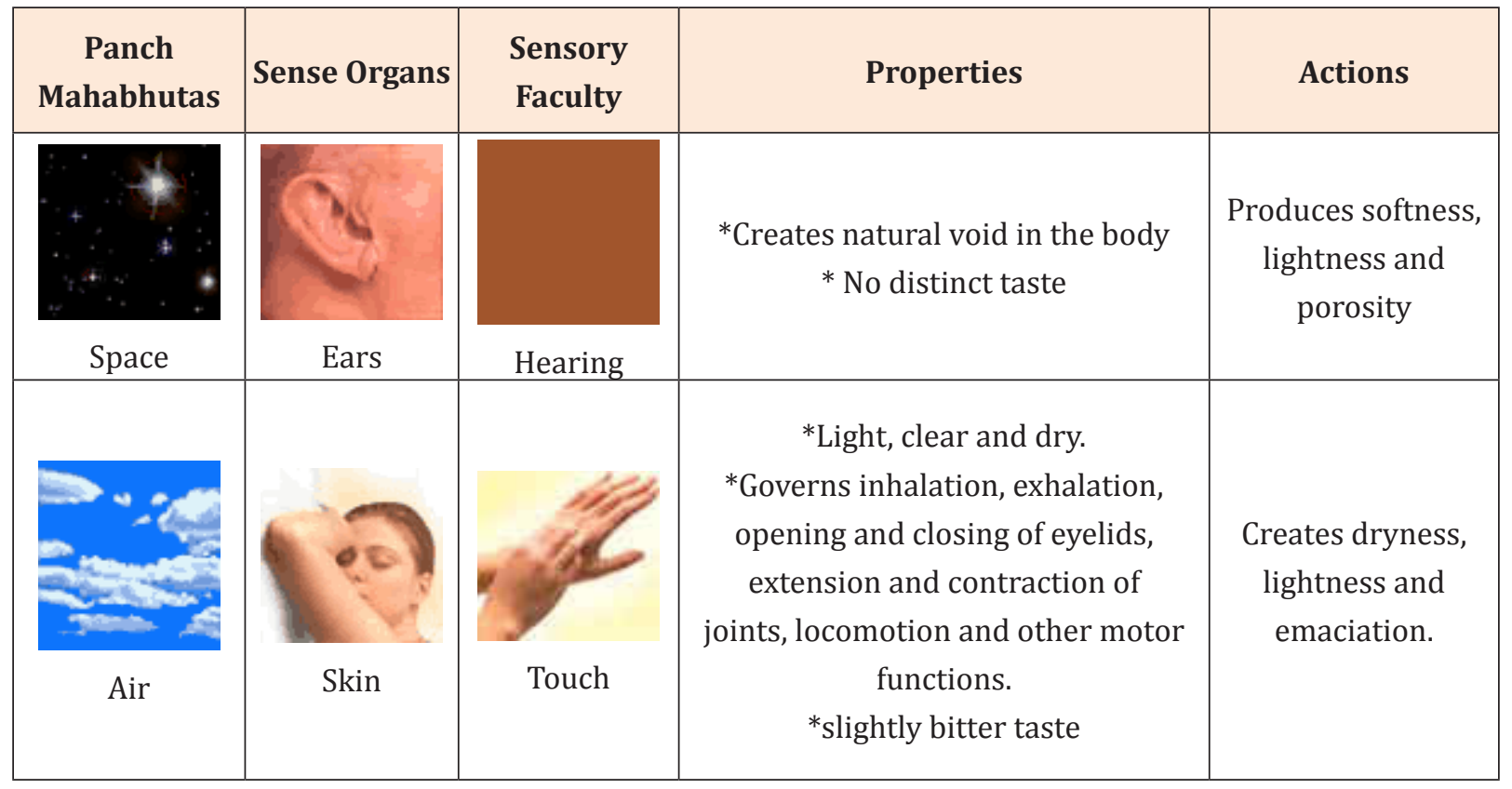




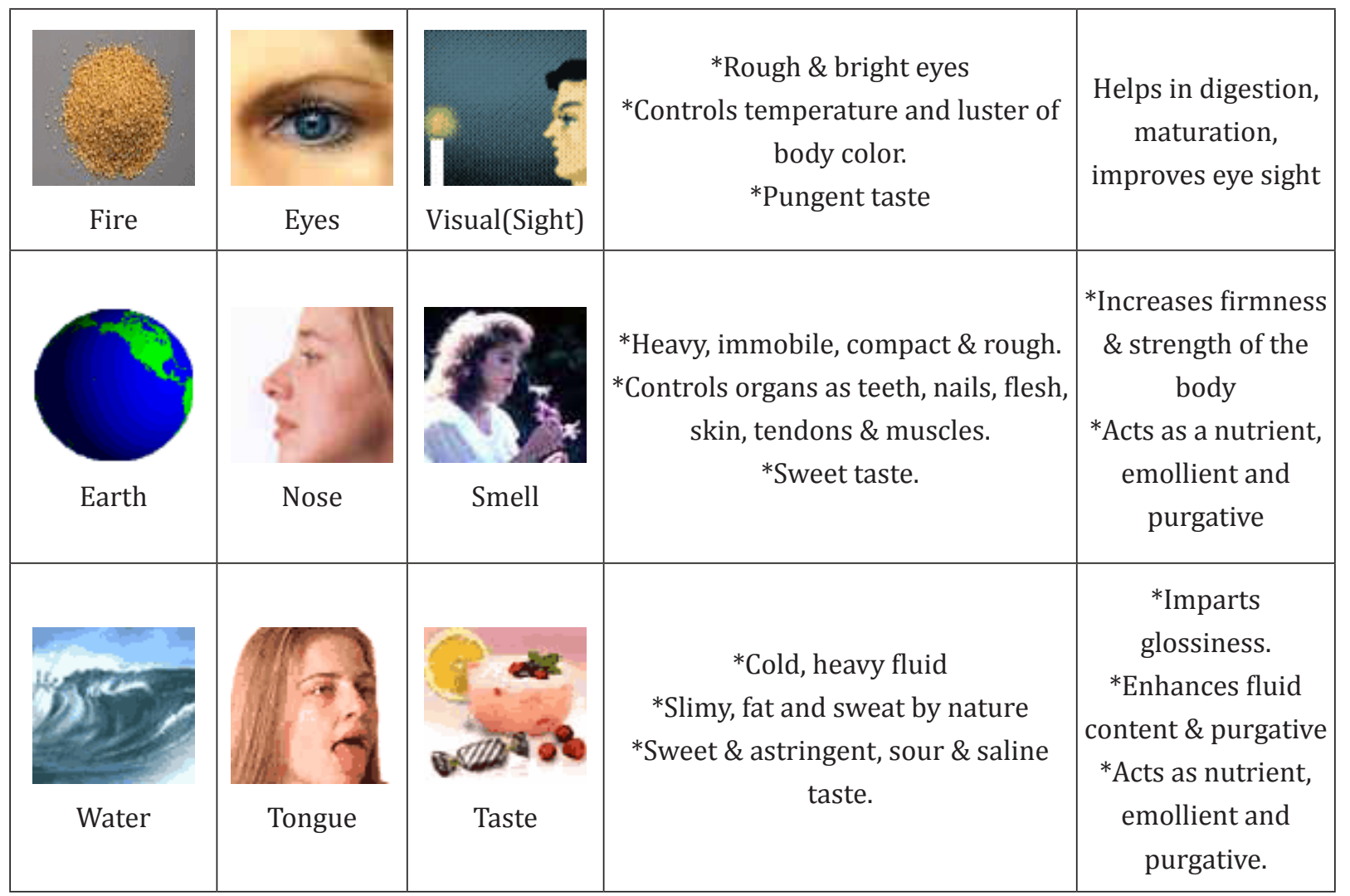

\section{F. Swastha vritta}

The meaning of "swastha vritta" is life style to live a healthy life.

All acharya wrote on swastha vritta in detail.

We can understand about swastha vritta mainly in following headings.

\section{G. Dincharya}

Dincharya means life style on daily basis.

In Sanskrit, the word 'dincharya' means daily routine. According to Ayurveda, one should follow the dincharya in order to lead a healthy and disease-free life. Every day, two cycles of change pass through the human body, each bringing a Vata, Pitta, or Kapha predominance. Based on the cycles of vata, pitta and kapha, our daily routine should be divided into morning, noon, evening/twilight, dinner and bedtime.

In the Ayurvedic texts, it is written that a person should wake up two hours prior to the sunrise, if he/she is not suffering from any diseases such as fever or diarrhea. Very young, very old and sick people are some of the exceptions. According to dincharya, the day should be kick-started by eliminating the colon and the bladder, followed by a thorough cleaning of the senses - ears, eyes, mouth etc. This should be followed by oil self massage. Exercise in the morning, just after the massage, helps rejuvenate the body and soul. After bathing, one should head towards the dining table for breakfast. The day follows by activities like studying, working or traveling. During the lunch, one should consume nutritious meal. After working for the day, twilight is the time to offer evening prayers. Dinner should consist of a light meal. Before going to bed, one should sit back and relax. By following the dincharya of Ayurveda, one can ensure a healthy life.

Though it is difficult to follow a stringent dinacharya in this fast moving life, it is highly recommended by Ayurvedic physicians, because a number of health benefits are associated with it. The dinacharya makes one to lead a healthy and disciplined life. According to the latest studies in the field of medical science, people who stick to the daily routine are more fit than those, who do not have a particular time to perform their everyday activities. It is said that dinacharya reduces the stress level to a great extent. In addition to this, the person's body is purified and detoxified. Therefore, barring a few exceptions like sickness, very old and young age, Ayurvedic dinacharya is recommended for everyone.

\section{H. Ancient daily regime}

The Ayurvedic classics give us detailed descriptions of how to maintain healthy and disciplined lifestyle. Charaka has given a comprehensive and detailed account of the mode of living and rules of good conduct to be followed if we want a good, healthy and happy life. The average span of life for human beings should be one hundred years, but this may decrease if the prescribed good conduct is not adhered to. 


\section{Modern dincharya}

The Ayurvedic classics give us detailed descriptions of how to maintain a healthy and disciplined lifestyle. According to the science of life, the average span of life for human beings is one hundred years, which may decrease if the prescribed good conduct is not adhered to. The ancient medicinal form suggests that in order to achieve the fourfold objective of life-dharma (virtuous duty), artha (wealth), kama (enjoyment) and moksha (salvation), we must have good health.

\section{J. Ritucharya}

Ritucharya means life style according to season of nature.

As we know that the climatic and seasonal changes have an important effect on the health of a person, it is important to make our body immune enough to adjust to those changes and adapt itself accordingly. Ayurveda recognizes that seasonal changes have a profound effect on our health, and recommends many helpful suggestions for how we can adapt our lifestyle to stay balanced in each season.

Ayurveda made the suggestions person specific because one lifestyle or diet cannot suit everybody as people have different constitutional make up. Seasonal Regime in Ayurveda According to Ayurveda the constitution or dosha of the body and the seasons are intimately related.

Our health is affected by the qualities of the climate we live in; our outer environment influences our inner world. For example, when the air is damp, cold and wet it increases these qualities in your body. Hence there is an increase in mucous, catarrh and colds in winter. There are various environmental factors like temperature, humidity, wind, rain, clouds and atmospheric pressure and sunlight etc that affect our health.

a. Winters: You must have noticed that when the temperature is extreme cold or extreme hot then there are maximum cases of illness. In such extreme conditions one may be freeze to death or die of sunstroke. One remains comfortable in temperature between $60^{\circ} \mathrm{f}$ and $76^{\circ} \mathrm{f}$ and humidity range of 40-70\%. In extremes of weather below / beyond these ranges, the body tries to maintain its internal temperature mainly by shivering when it is too cold and through perspiration when it is too hot.

b. Summer: In summer season, one should avoid sunlight; eat less of fat food, oil, and meat, sleeping during daytime and the eastern winds. Sour, salty and pungent foods, should also be avoided, as they tend to increase pitta. The diet mainly consisting of sweet, bitter, cold and light items that pacify pitta should be taken. The strength and digestive power are poor in summer. Hence one should restrict the food intake in this season. Cold food items should be taken to counteract the effect of the hot season.

c. Monsoon: In the monsoon all the three doshas are vitiated. Light diet and less oily food are advised, as digestive power is weak. It is better to take as much as fluids as possible. One should not follow this regime mechanically but should try to understand the meaning and purpose behind it. The daily and seasonal regime should be modified according to the age, sex, region, food habit, physical stamina, digestive power, mental health and condition of health. The central teaching of Ayurveda is that in order to optimize your health you must clear the accumulation of the doshas from your system. Any increase in the doshas can cause illness.

Swastha vritta tell us that what should we have to do for healthy life. Here healthy means well being of mental, physical, anatomical health.

\section{Treatment}

To know about ayurvedic treatment, we have to classify like that,

\section{Shaman chikitsa}

Shaman Chikitsa, used to subdue the vitiated Doshas, due to which any ailments may be produced. It is administered by using various medicinal herbo-mineral preparations.

\section{Shodhan chikitsa}

Shodhan chikitsa means treatment to remove or excrete out the increased/affected dosh from the body.

Acharya says that treatment by shodhan is very effective and long lasting more than shaman chikitsa. Every human must use shodhan treatment once in a year for healthy living. Generally, shodhan treatment also known as Panchakarma treatment Shodhan chikitsa (Purification of the body according to the ayurveda) has following treatment procedure.

A. Pre-panchakarama procedure: it makes body to start panchkarma for appropriate results. It includes Snehan (internal \& external lubrication), Swedan (internal and external heating).

Snehan (oleation/massage) and Swedan (steam) are associated procedures which should be done before pradhan karmas and are so called Purva karma. Purva karma is a preparatory stage for the main procedures, it brings the aggravated doshas in koshtha for their elimination. Snehan (Massage /Oleation therapy) and Swedan (Sudation) are the two Purva karmas.

i. Snehan: Snehan or Oleation therapy helps in loosening the bodytoxins which are stuck up into our body systems causing ailments. Oleation is of two types internal and external oleation, where in Internal Oleation Sneha dravya like plain or medicated ghee, oil is taken orally in desirable amount. External Oleation therapy consists of whole or partial body massage with medicted oils. Our skin being semi-permeable absorbs this oil to some extent.

ii. Swedan: Swedan or Sudation therapy is sweating induced by steam,it liquifies the toxins and increases the flow of toxins to Gastrointestinal tract (Koshtha). There are various ways of applying swedan therapy like Nadi sweda, Pinda sweda, Patra pottali, Valuka sweda, etc the type of sweda to be used is selected according to patient and the disease he is suffering from. 
Similarly there are other associated procedures apart from these basic five therapies which will be dealt further,but to mention a few they are : Shirodhara, Shirobasti, Katibasti, Janubasti, Netra tarpan, Karnapuran, Pizicchil, Tailadahara, Nabhipuran, Hridbasti, Manyabasti, etc.

\section{B. Panchakarma}

Acharya Charaka first used the term Panchakarma. He included following 5 procedures or therapies in Panchakarma:

a. Vamana; b. Virechana; c. Asthapana Basti; d. Anuvasana Basti; e. Shirovirechana Sushruta-samhita, Ashtanga-sangraha and Ashtanga-hridaya described following Samshodhana-karma:

\section{a. Vamana; b. Virechana; c. Basti; d. Nasya; e. Raktamokshana;}

These are the Pradhana-karma (main procedure) of Panchakarma as described in Bhrihattrayee.

a. Vaman (Therapeutic emesis): Vamana treatment is targeted to expel increased Kapha Dosha out of the body. When Kapha dosha gets increased, it causes certain types of diseases- such as cold, cough etc. If the extent of Kapha increase is less, then some oral medicines can be given to suppress it. But if it has increased to a large extent and if it has moved from its natural place to other places, then it needs to be expelled out of the body. By expelling it out, the disease gets cured, often completely. Since Kapha is situated in the chest region, expelling it from the oral route is very easy. Hence, Vamana treatment is designed. To expel it out first the Kapha Dosha needs to be forcefully brought from the extremities and different organs into the stomach, and then vomiting is induced.

b. Virechan (therapeutic purgation): Virechan is given to patients suffering from Pitta dosha related diseases. It cleanses the GastroIntestinal tract thoroughly and voids off the Pitta toxins accumulated in the liver, gall bladder and small intestine. Purgation is given with medicines like Cows milk, Black currants, castor oil, etc.It is a safe procedure without side effects. Virechana helps to cure Chronic Fever Diabetes, Asthma, Skin disorders such as Herpes, Paraplegia, Hemiplegia, Joint disorders, Digestive disorders, and Constipation, Hyperacidity, Vitiligo, Psoriasis, Headaches, Elephantiasis and Gynecological disorders.

c. Basti (therapeutic enema): Basti is considered to be the most effective treatment in Ayurveda as it not only prime cure for Vata disorders but also cleanses toxins created by pitta and kapha through rectum. Medicated oil, ghee or decoction is introduced through anus into the colon. Basti is an effective therapy in osteoporosis, gas trouble, constipation, backache, hemiplegia, paraplegia, sciatica, cervical spondylosis, chronic fever, arthritis, muscle spasm, acidity, digestive disorders, joint pain, slip disc, sexual disorders,etc.and other ailments caused due to imbalance of vata dosha. The large intestine,and bones are the main seat of vata, so Basti is administered through rectum which removes toxins and also nourishes the membrane of colon and controls vata diseases efficiently. d. Nasya ( Nasal drop): Medicine instilled into nose is known as Nasya. It acts on doshas accumulated in head, neck and face region, especially kapha dosha. It drains out sinus,relieves headache,improves eye sight, memory and promotes hair growth. Nasal allergies, polyps, neck stiffness, frozen shoulder, Bell's palsy can be well treated by Nasya. In cases of Hemiplagia and Paraplegia it stimulates brain tissues and improves functioning of nervous system.

e. Raktmokshan (blood letting): Raktamokshan is a unique procedure specially performed in disease due to Pitta and Rakta dushti. Raktamokshan is carried out in various ways but the most common techniques used are application of Leeches and blood letting with syringe. Leeches suck impure blood from our body and are usually helpful in localised area. It reduces pain and swelling in joint pain, localised skin diseases, cracked heels,vericose veins, etc. Blood letting through syringe is effective in generalised body ailments like Hypertension, Large area of Vericose veins, Vitiligo, severe Headache,etc.

These fivefold therapies work wonders when performed properly under supervision of well experienced, efficient Ayurvedic consultant and obedient patient who is willing to follow all the necessary rules Do's and Dont's as advised by the Doctor.

C. Post- panchakarma procedure: After complete panchakrma, body want to get normalize through step by step activities like digestion etc. because after panchkamrma physiology of human body becomes weak. That's why person who had panchkarm must follow a particular system to regain his normal metabolism and physiology.

It includes-

i. Sansarjan Krama (to increase digestive power of the body and to normalize the physiology of the body)

After the elimination of the Dosa by any one measure the Pañcakarma, for improving digestion and assimilation and also for regaining strength and vitality, Paścāta Karma is indicated. In Paścāta Karma, the steps of gradual dieting and exercise have been mentioned. For taking the patient to his normal diet, the diet should begin with Peyā, then Vilepī, KṛtaYūṣa, AkṛtaYūṣa, Māmsa-Rasa with the increase in quantity and quality gradually; this process is known as SamsarjanaKrama. The dietary regime for PravaraŚuddhi is as follow:

On the evening of performing Śodhana e.g. Vamana, or Virecana etc. Yavāgu should be given. In the same way Yavāgu should also be given for the next day for two meals i.e. in the noon and evening. At the fourth meal time, Vilepi (thick gruel) with or without Sneha and salt should be administered. The same diet on fifth and sixth meal time should be taken. At the seventh meal time he may be given well cooked rice with gree green soup mixed with a little of Sneha and salt. The same to be given on the eighth and ninth meal time. At the tenth meal time he may be given rice with meat juice. The same should be repeated at the eleventh and twelfth meal time. Thereafter the patient should take normal diet gradually as on the seventh night he returns to the normal state. 
ii. Shirodhara: (to relax the mind. Ex. Insomnia, epilepsy, hypertension etc.) Shirodhara is a form of Ayurveda therapy that involves gently pouring liquids over the forehead and can be one of the steps involved in Panchakarma. The name comes from the Sanskrit words shiro (head) and dhara (flow).

Modern lifestyles lead to poor health in many ways. However, the use of simple and natural methods can significantly improve health and vitality. Purification therapy is a unique feature of Ayurveda involving the complete cleansing of body and thereby eliminating vitiated doshas. The technique effectively treats doshic balances in their advanced stages. Vitiated doshas causing blocked channels in a system, which needs purification, approach. Shirodhara is one of the great purification and rejuvenating therapy.

Shirodhara is an ancient Ayurvedic healing practice performed in India for over 5,000 years. The word shirodhara breaks down into two ideas: shiro, meaning head, and dhara which means flow. Together they form a concept that aims to bring physical and emotional balance by rejuvenating the spirit and preserving health. This is achieved through a relaxing technique in which warmed oil is poured over a client?s forehead for an extended period of time.

There are specialized forms of shirodhara called tailadhara, ksheeradhara, takradhara and jaladhara.

Shirodhara is traditionally used to calm the nerves, harmonize vata constitutions, restore the nerves, release stored emotions, and purify the mind. In Ayurvedic Medicine, it is considered an important tool in the pursuit of higher states of consciousness. Shirodhara has been traditionally shown to help with fatigue, mental exhaustion, anxiety, insomnia, some mental disorders, headache, excessive thinking, nervousness, and many other conditions commonly affecting persons in today?s active lifestyle.

a. Benifits of Shirodhara: Memory, nourishes hair and scalp, assists in providing sound sleep and calms the body and mind. Shirodhara is one of the most effective treatments for reducing stress and nervous tension.

i. Ultimate mental and emotional relaxation therapy.

ii. Beneficial for many diseases connected with the head, neck, eyes, ears, nose and throat.

iii. Beneficial for many diseases of the nervous system like nerve disorders, facial palsy, paralysis and ptosis (drooping) of the eyelids.

iv. Beneficial for curing long standing insomnia and schizophrenia.

v. Beneficial for fits in epilepsy when used in conjunction with other medicines.

vi. Prevents hair lose, premature graying and cracking of hair.

vii. Relieves headache and burning sensation of the head.

viii. Nourishes and rejuvenates the body ix. Stimulates the nervous system giving sturdiness to the body.

x. Improves digestion.

xi. Sharpens the sense organs.

xii. Improves the quality of voice.

xiii. Gives strength to the neck and head.

xiv. Improves the health of the skin.

xv. Cools the body and relieves pain.

xvi. Invigorates the body and mind and stimulate cognitive memories.

xvii. Helps relieve fatigue, tension, anxiety, anger, chronic headaches, rheumatism, hypertension, asthma, hair problems and stress.

xviii. Disperses negative electrical impulses that accumulate at the skull and hairline from stress.

xix. Renews the sweetness of life.

xx. Rejuvenates the entire face and softens worry lines.

xxi. Opens the third eye of lord Shiva by this therapeutic Marma based head massage.

xxii. Activates the pituitary gland.

xxiii. Increases spiritual awareness.

xxiv. Regulates mood and depression disorders.

xxv. Activates the memory \& stimulates the 6 \& 7 th charka which regulates our breathing patterns.

xxvi. Increases intuition.

xxvii. It improves concentration, intelligence, confidence and selfesteem

\section{b. Contraindications for Shirodhara therapy}

i. Full stomach.

ii. Severe Vata.

iii. People with severe anxity and combined control issues.

iv. Low Blood pressure.

v. Pregnancy.

vi. Recent neck injuiry.

vii. Alcoholism.

viii. Brain tumor.

ix. Abrasions or cuts on head.

x. Rashes on forehead or scalp.

xi. Aversion to oil. 